\title{
Kesiapan Orang Tua Dalam Mendukung Pembelajaran Di Masa Pandemi COVID-19
}

\author{
Resti Warliani ${ }^{1}$ Salma Arfa Fauziyyah ${ }^{2}$ \\ restiwarliani@uniga.ac.id ${ }^{1}$ \\ Universitas Garut
}

\begin{abstract}
Abstrak
Penelitian ini bertujuan untuk mengetahui gambaran kesiapan orangtua siswa dalam mendukung pembelajaran ketika diberlakukan Study From Home di masa pandemi covid-19. Metode penelitian yang dilakukan adalah metode kualitatif-deskriptif melalui survey dengan menggunakan angket google form. Hasil penelitian menunjukkan bahwa : (1) Orangtua memiliki ketertarikan yang positif terhadap pembelajaran daring, (2) Sebanyak 80\% menyatakan memiliki fasilitas yang memadai dalam pembelajaran daring, (3) Sebanyak $68 \%$ menyatakan melakukan pendampingan dalam pembelajaran daring, (4) Sebanyak 34\% menyatakan metode yang dilakukan guru dalam pembelajaran daring adalah pemberian materi dalam bentuk soft file atau tugas.
\end{abstract}

Kata kunci : Pandemi Covid-19, Pembelajaran Daring, Study From Home,

\section{Pendahuluan}

Pandemi Covid-19 telah melanda lebih dari 200 Negara di dunia termasuk Negara Indonesia (Sadikin\&Hamidah, 2020). Salah satu sektor yang terkena dampaknya adalah dunia pendidikan (Purwanto, 2020). Upaya yang harus dilakukan untuk mencagah terjadinya penyebaran virus covid 19 ini telah direkomendasikan oleh World Health Organization (WHO) yaitu dengan menghentikan kegiatan-kegiatan yang melibatkan kerumunan massa. Kementerian Pendidikan dan Kebudayaan (Kemendikbud) telah mengeluarkan surat edaran (Kemendikbud Dikti No.1 tahun 2020) yang menginstruksikan untuk melakukan kegiatan pembelajaran jarak jauh untuk mencegah penyebaran covid-19. Salah satu solusi yang dilakukan dalam pembelajaran jarak jauh ini adalah dengan melaksanakan pembelajarn secara daring (dalam jaringan) melalui pemanfaatan Teknologi dan Informasi. Adapun pembelajaran daring ini bertujuan untuk memenuhi standar pendidikan dengan pemanfaatan Teknologi Informasi dengan menggunakan perangkat komputer atau gadget yang saling terhubung antara pendidik dengan peserta didik sehingga proses belajar mengajar dapat terlaksana dengan baik (Pakpahan\&Fitriani, 2020). Ada beberapa teknologi informasi yang bisa digunakan dalam pembelajaran daring saat ini diantaranya memanfaatkan aplikasi Google Classroom, Whatsapp, Zoom, Learning Management System (LMS) dll. 
Tantangan yang dihadapi dalam pembelajaran daring ini adalah keahlian dalam penggunaan teknologi baik dari pihak pendidik maupun peserta didik (Handarini, 2020). Dabbagh (dalam Hasanah, dkk) menjabarkan tentang ciri-ciri peserta didik dalam aktivitas pembelajaran secara daring, yaitu :

1. Semangat belajar. Peserta didik pada pembelajaran daring harus memiliki semangat yang tinggi dengan melakukan pembelajaran secara mandiri. Kemandirian belajar dari peserta didik akan menentukan keberhasilan dari pembelajaran daring.

2. Literasi terhadap Teknologi. Pemahaman peserta didik dalam penggunaan teknologi merupakan keberhasilan dari pembelajaran daring tersebut. Penguasaan teknologi merupakan keterampilan yang harus dimiliki peserta didik untuk mendukung terlaksananya pembelajaran daring. Alat yang sering digunakan dalam pembelajaran daring diantaranya adalah laptop atau gadget yang didalamnya memuat aplikasi yang mendukung untuk pembelajaran daring ini.

3. Kemampuan berkomunikasi intrapersonal. Peserta didik harus menguasai kemampuan komunikasi dan kemampuan intrapersonal agar pembelajaran daring dapat terwujud dengan baik. Sebagai mahluk sosial tetap membutuhkan interaksi satu dengan yang lainnya meskipun pembelajaran daring dilakukan secara mandiri.

4. Berkolaborasi. Dalam pembelajaran daring ini, peserta didik harus mampu berinteraksi satu sama lain, baik dengan sesama peserta didik maupun dengan gurunya. Interaksi ini diperlukan ketika peserta didik mengalami kesulitan memahami materi . Selain itu, interaksi ini juga bertujuan agar jiwa sosial tetap terbangun meskipun pembelajaran dilakukan secara daring.

5. Kemampuan untuk Belajar Mandiri. Kemampuan belajar secara mandiri merupakan karakteristik dalam pembelajaran daring. Dalam pembelajaran daring ini diperlukan keterampilan belajar secara mandiri karena pada proses belajar, peserta didik akan mencari, menemukan dan menyimpulkan materi yang dipelajari secara mandiri.

Dalam pembelajaran daring, peran pendampingan orang tua pun sangat diperlukan baik dukungan secara langsung ataupun tidak langsung. Pada penelitian ini, peneliti ingin melakukan studi pendahuluan mengenai gambaran kesiapan Orang Tua dalam mendukung Pembelajaran di masa Pandemi Covid-19.

\section{Metodologi}

Metode yang dilakukan dalam penelitian ini adalah penelitian kualitatif-deskriptif tentang kesiapan orangtua dalam mendukung pembelajaran di masa pandemi covid19. Pengumpulan data yang dilakukan menggunakan angket dengan google form yang disebarkan melalui aplikasi whatsapp dan instagram. Subjek penelitian sebanyak 56 responden yang merupakan orangtua siswa di Desa Keresek, Kecamatan Cibatu Kabupaten Garut. Pertanyaan yang diajukan dalam angket tersebut meliputi (1) Fasilitas, (2) Pendampingan dalam pembelajaran, (3) Ketertarikan dalam pembelajaran daring, dan (4) Metode yang dilakukan oleh Guru. 


\section{Hasil dan Diskusi}

Berdasarkan angket yang diberikan, diperoleh presentase ketertarikan responden dalam pembelajaran daring. Ketertarikan diukur dalam skala rentang 1-10, nilai 1 responden tidak tertarik dalam pembelajaran daring sedangkan nilai 10 responden sangat tertarik dalam pembelajaran daring. Semakin poin ke kanan (nilai semakin besar), semakin tinggi ketertarikan responden dalam pembelajaran daring.

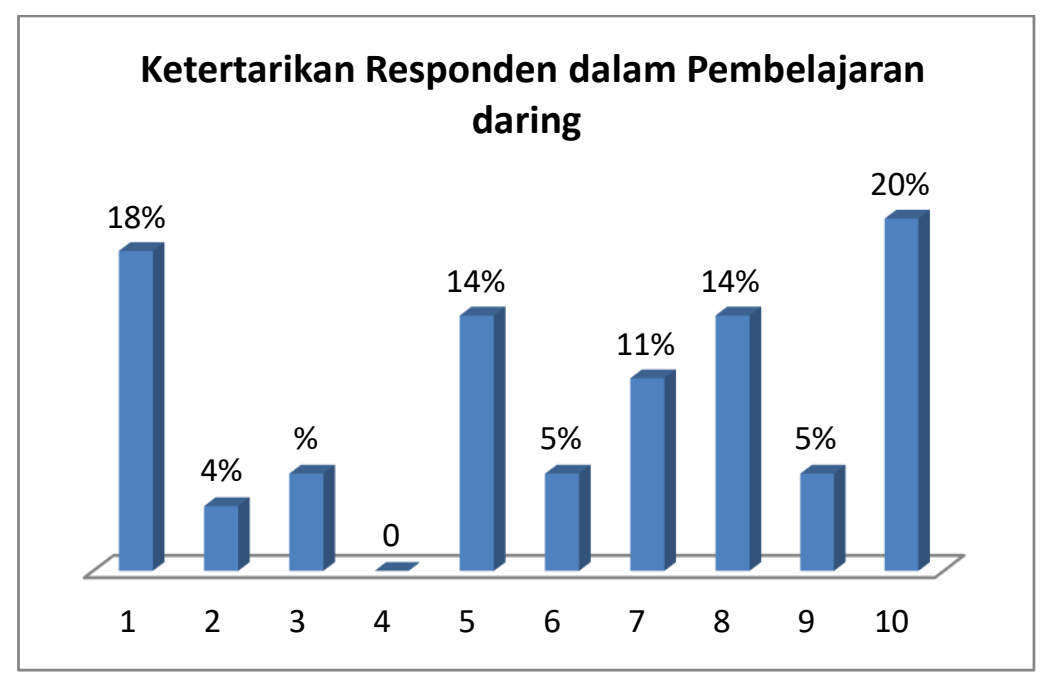

Grafik 1. Presentase Ketertarikan Responden dalam pembelajaran daring.

Dari hasil grafik 1 diperoleh bahwa sebanyak $20 \%$ responden sangat tertarik terhadap penggunaan media daring untuk pembelajaran dan sebanyak $18 \%$ responden tidak tertarik dalam penggunaan media daring untuk pembelajaran. Secara keseluruhan presentase terbesar menunjukkan responden tertarik dalam penggunaam media daring dalam pembelajaran.

Untuk mengkukur tanggapan responden dalam menyebutkan metode yag dilakukan guru dalam pembelajaran daring, ada 5 pernyataan yang diberikan dalam angket tersebut. Pernyataan tersebut dapat dilihat dari Tabel 1.

Tabel 1. Instrumen Tanggapan Mengenai Metode Yang Dilakukan Guru Dalam

Pembelajaran Daring

\begin{tabular}{|c|l|}
\hline Tanggapan & \multicolumn{1}{|c|}{ Pernyataan } \\
\hline 1 & Pemberian materi melalui media daring kemudian tanya jawab \\
\hline 2 & Pemberian materi dalam bentuk soft file atau tugas \\
\hline 3 & Pemberian materi dan tugas secara langsung \\
\hline 4 & Pemberian tugas saja \\
\hline 5 & Lainnya \\
\hline
\end{tabular}


Berikut merupakan grafik yang menunjukkan presentase metode yang digunakan guru dalam pembelajaran Daring.

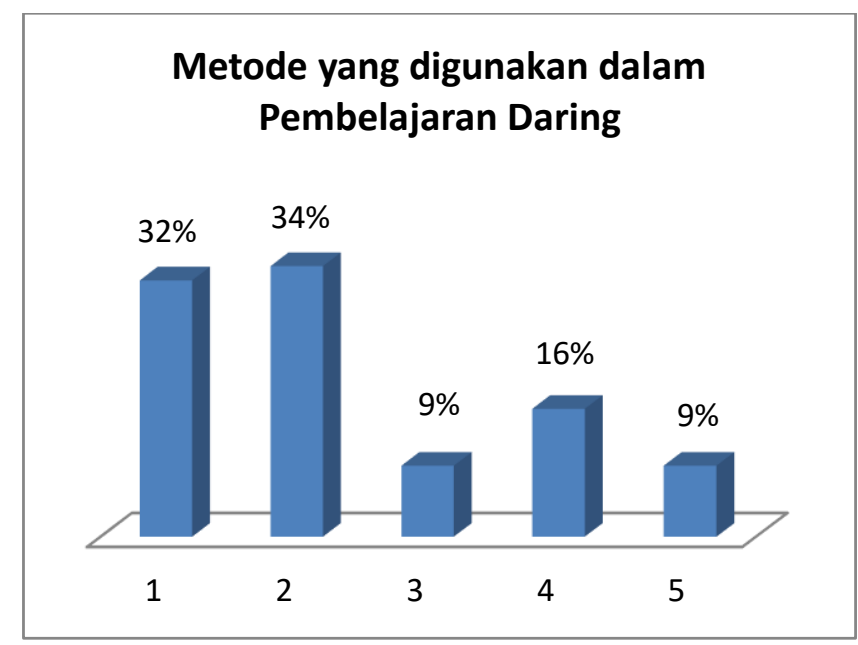

Grafik 2. Presentase Metode yang digunakan guru dalam pembelajaran daring

Dari grafik 2 terlihat bahwa Pemberian materi dalam bentuk soft file atau tugas merupakan metode yang paling banyak dilakukan guru dalam pembelajaran daring yaitu sebanyak 34\%. Selanjutnya diikuti dengan metode Pemberian materi melalui media daring kemudian tanya jawab, sebanyak 32\%. Pemberian materi dan tugas secara langsung menjadi metode yang paling sedikit digunakan oleh guru dalam pembelajaran daring, yaitu sebanyak $9 \%$.

Dalam pembelajaran daring tidak terlepas dari fasilitas yang harus ada untuk mendukung kelancarannya. Berdasarkan hasil angket yang diberikan menunjukkan $80 \%$ orangtua siswa memiliki fasilitas yang mendukung dan $20 \%$ orangtua siswa tidak memiliki fasilitas yang mendukung.

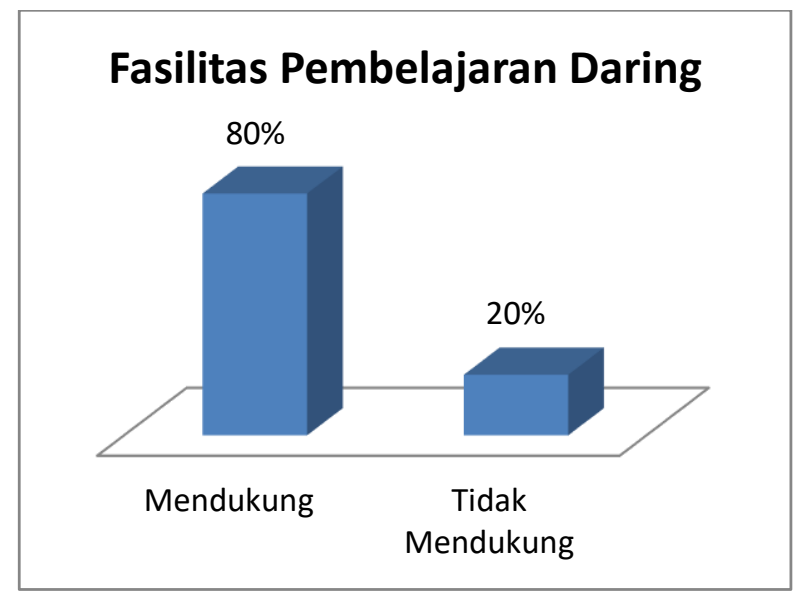




\section{Grafik 3. Presentase Fasilitas Dalam Pembelajaran Daring}

Dalam pembelajaran daring ini, pendampingan orang tua memiliki peran yang penting. Berdasarkan hasil kuesioner diperoleh bahwa $68 \%$ orangtua melakukan pendampingan terhadap anaknya ketika pembelajaran daring, sebesar $23 \%$ menyatakan tidak mendampingi anaknya dalam pembelajaran daring dan sisanya 9\% menyatakan kadang-kadang melakukan pendampingan dalam pembelarang daring.

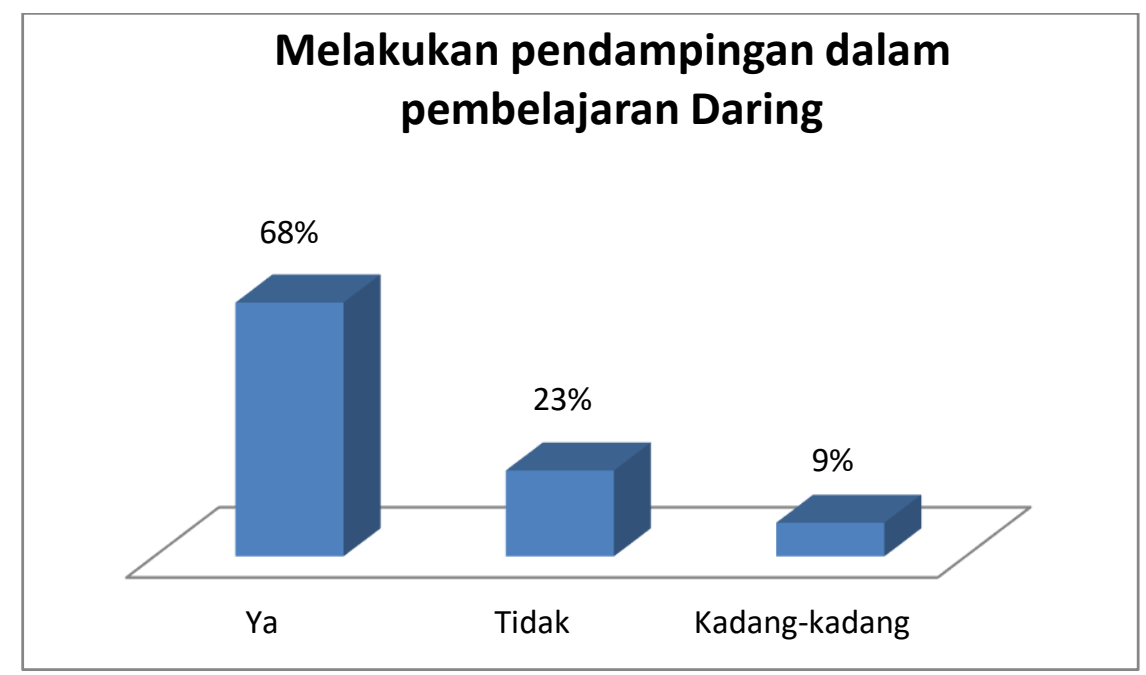

Grafik 4. Presentase Pendampingan dalam Pembelajaran daring

Berdasarkan hasil yang diperoleh tersebut, dapat dikatakan bahwa orangtua sudah ikut berperan dalam pembelajaran daring. Mayoritas responden beralasan mendampingi anaknya ketika pembelajaran merupakan tugas yang harus dilakukan karena anak masih perlu bimbingan dan pantauan dalam mengerjakan tugas dari gurunya. Untuk Responden yang menjawab tidak mendampingi anaknya dalam pembelajaran daring mayoritas beralasan karena orangtua sibuk bekerja. Adapun responden yang mengatakan kadang-kadang beralasan jika anaknya tidak mengalami kesulitan, dibiarkan saja.

\section{Kesimpulan}

Berdasarkan hasil data yang diperoleh dapat disimpulkan bahwa Orangtua memiliki kesiapan yang baik dalam pembelajaran daring. Hal tersebut ditunjukkan dari respon positif orangtua terhadap pembelajaran daring baik dari Fasilitas yang 
memadai dalam pembelajaran daring, Pendampingan dalam pembelajaran, Ketertarikan dalam pembelajaran daring, dan Metode yang dilakukan oleh Guru.

\section{Saran}

Saran untuk penelitian selanjutnya yaitu memfokuskan pada metode pembelajaran yang dilakukan oleh guru dalam penggunaan sumber belajar atau media yang digunakan dalam pembelajaran daring.

\section{Daftar Pustaka}

Handarini, O.I. 2020.Pembelajarann Daring Sebagai Upaya Study From Home (SFH) Selama Pandemi Covid-19. Jurnal Pendidikan Administrasi Perkantoran. Volume 8, No.3.

Hasanah,dkk.2020.Analisis Belajar Daring Mahasiswa Pada Pandemi Covid19.Jurnal Pendidikan. Volume 1, No. 1.

Pakpahan,R \& Fitriani,Y.2020. Analisa Pemanfaatan Teknologi Informasi dalam Pembelajaran Jarak Jauh di tengah pandemic virus corona covid-19. Journal of Information System, Applied,Management,Accounting and Research. Volume 4, No.2.

Purwanto,dkk.2020. Studi Eksploratif Dampak Pandemi Covid-19 Terhadap Proses Pembelajaran Online di Sekolah Dasar. Journal of Education, Pshycology, and Counselling. Volume 2, No.1.

Sadikin,A\&Hamidah,A.2020.Pembelajaran Daring di tengah wabah covid-19. Jurnal Ilmiah Pendidikan Biologi. Volume 6.No.2.

Surat Edaran Kementerian Pendidikan dan Kebudayaan (Kemendikbud) Direktorat Pendidikan Tinggi No.1 Tahun 2020. 